\title{
THE FUTILITY OF BEING HELD CAPTIVE BY LANGUAGE POLICY ISSUES IN APPLIED LINGUISTICS: AN ARGUMENT FOR IMPLEMENTATION
}

\author{
Sinfree Makoni
}

\begin{abstract}
Some South African Applied Linguists and political language activists are currently operating in a policy mode. This paper argues that the continued interest in and preoccupation with language policy issues arises from an interplay of two factors:

(1) Overconfidence in the role that a new language policy could play in effecting change particularly in education

(2) Overconfidence in the beneficial impact of innovations.
\end{abstract}

The paper also argues that trust in the effectiveness of language policy is misplaced because many language problems cannot readily be solved by planning unless detailed attention is paid to what is necessary for policy to be implemented and evaluated. The paper concludes by proposing how such detailed implementation could be carried out.

\section{OPSOMMING}

Party Suid-Afrikaanse toegepaste taalwetenskaplikes en politieke taalaktiviste werk tans in 'n beleidsmodus. In hierdie referaat word aangevoer dat die volgehoue belangstelling en preokkupasie met taalbeleidsake voortspruit uit die wisselwerking van twee faktore:

(1) Oormatige vertroue in die rol wat ' $n$ nuwe taalbeleid kan speel om verandering te bewerkstellig, veral in die opvoedkunde

(2) Oormatige vertroue in die voordelige impak van nuwighede.

In hierdie referaat word ook aangevoer dat die vertroue in die effektiwiteit van taalbeleid misplaas is omdat baie taalprobleme nie geredelik deur beplanning opgelos kan word nie, behalwe as gedetailleerde aandag gegee word aan dit wat nodig is om 'n beleid te implementeer en te evalueer. Die referaat word afgesluit met voorstelle oor hoe hierdie gedetailleerde implementasie uitgevoer kan word.

\section{INTRODUCTION}

This paper is divided into three parts. The first evaluates the continued interest in language policy issues in South African Applied Linguistics. The second part tries to provide an explanation for the continued interest in language policy, arguing that language policy is one of the fads in Applied Linguistics.

The third part of the paper makes a case for attention to issues of implementation by arguing that what should be central in policy formulation is the degree of implementability of the policy and not its political popularity or marketability. 


\section{DETERMINING THE POPULARITY OF LANGUAGE POLICY ISSUES IN SOUTH AFRICAN APPLIED LINGUISTICS}

"There are fashions in these matters as in everything else" (Lyons 1992: 262).

Our concerns in Applied Linguistics, as in other areas of education, may be influenced much more strongly by fashion than we are prepared to admit. The impact of fashion on Applied Linguistics is not necessarily always a bad thing. What is bad, however, is that fashion can become so tyrannical that as Davies (1977: 1) restated in Davies (1993: 14) points out we become "reluctant to submit our guess work to the rigour of hypothesis and experimentation" because we fear our ideas are more valid politically than intellectually.

It is certainly more fashionable to investigate some areas of Applied Linguistics than others. For example, studying language policy issues may be regarded as more fashionable than investigating the reading problems of second language users. The former has a higher political surrender value then the latter, even though our rational selves might make us feel that concentrating our investigatory efforts on reading problems may be a more economic way of using our intellectual resources than debating the possible language options future governments might follow. Decisions about language policies are essentially "political" (Whiteley 1974; Treffgarne 1986).

The recently announced eleven languages policy is an excellent example of how decisions about language policy are primarily political, settled in a "court of politics" in which input from Applied Linguists is at best minimal.

One way of assessing the popularity of some areas of academic enquiry is through investigating topics which are the subjects of 'talk' at local and international conferences. An analysis of such talk would form part of what I would call an ethnography of conferencelogy - a heavily underresearched area. The limited research into an ethnography of conferencelogy holds some interest because I suspect most academics would agree that, funds. permitting, conferencing plays an integral role in our intellectual life. One advantage of conducting an ethnography of conferences is that all papers read at conferences do not necessarily find their way into print. Thus, conferencelogy may be a more reliable and valid index of the popularity of a topic than simply listing items in a bibliographical essay.

Conferences play a dual role in generating and sustaining interest in some academic areas. The selected topics are felt to be of sufficient interest among academics, or more cynically the selected topics are ones which some academics feel should be of interest to the intellectual community.

As conferences can reflect prevailing intellectual interests and help set agendas, it is worth examining recent conferences that devoted time to language policy issues.

The fifth conference of the Association of South African Applied Linguistics (SAALA) was held at the University of Cape Town in 1986. One of the themes of the conference was language planning in education. Twelve papers were selected and finally appeared in a collection edited by D. Young (1987).

An analysis of the conference documents shows that 6 out of a total of 43 presentations focused on language planning at the 1989 Conference which was held at the University of Witwatersrand. But in the book which emanated from the conference, edited by $\mathrm{K}$. Herbert (1992), the language planning and policy sections had become numerically dominant. One can only speculate on what transpired between the conference and the final publication of the book. But, whatever the case, it seems clear that language planning and policy are popular concerns, which are seen as worthy to be "embalmed" in print, perhaps even more so during the printing stage than during the conference itself. 
In 1992, language planning again featured prominently at a conference held at the University of Cape Town organised under the auspices of SAALA. The physical presence of $\mathrm{C}$. Kennedy and the satellite link with J.W. Tollefson in the U.S.A. highlighted the importance of language planning at that conference. Both Tollefson and Kennedy are well known in Applied Linguistic circles because of their work in language planning. Tollefson had recently published a book entitled Planning language planning inequality.

The 1993 conferences held at the Universities of Pretoria and the Witwatersrand had special sessions which addressed issues on language planning. Like the 1992 conference at the University of Cape Town, language policy issues were given a high profile by the physical presence of prominent scholars in language policy in the field - M.E. Kashoki and E.G. Bokamba. Even more recently in September 1993, a conference held at the University of Lesotho and organised by LICCA devoted a considerable amount of time to issues of language policy. Bamgbose who had recently published a book on language planning entitled Language and the Nation: The Language Question in Subsaharan Africa was scheduled to attend the conference, again emphasizing the importance attached to language planning issues.

This view on the current popularity of debates about language policy in South African Applied Linguistics is not new. A similar argument was made earlier by Du Plessis (1987: 17) when he argued that "the language policy and planning issue is in some way one of the fads of South African Linguistics. Whether it is due to blow over soon still has to be seen, taking the seriousness of the South African situation into account." I regard my argument here as an extension of Du Plessis's.

\section{IS IT NECESSARY FOR LANGUAGE PLANNING TO ATTRACT SO MUCH ATTENTION?}

This part of the paper begins by situating interest in language planning in an international context. Interest in language planning is not a peculiar characteristic of South African Applied Linguistics; it is an area of interest which has been revived in British Applied Linguistics. For example, the title of the 1991 annual meeting of the British Association of Applied Linguistics (BAAL) was Language and Nation, suggesting that there might be more similarities between former Eastern Europe and Third World conditions in South Africa than most people are prepared to admit in public (see Phillipson and Skutnabb-Kamgas 1994). The revival of interest in issues in language planning at BAAL could be attributed to the political events in former Eastern Europe.

The overwhelmingly contemporary perspective on planning in South African Applied Linguistics is odd. Rarely are detailed historical accounts of pre-colonial language policies given because of an excessive concern with current issues. On those few occasions when language analysts demonstrate a sharp and welcome sense of historical consciousness, the history of language policies is traced back either as far as colonial times or the arrival of missionaries, whichever is the earlier (Phillipson 1992; Wardhaugh 1987). This view on language policy is unduly modernistic because it forcefully creates an impression by default that issues about language policy were non-existent prior to the arrival of Europeans in Africa. Such a view is inaccurate. It overlooks the extent to which issues about language policy are intricately interwoven into the history of precolonial African formations. Laitin (1992) cites interesting evidence of a contrast between the language policies of nomadic and agricultural based African formations in East Africa.

\section{WHAT IS LANGUAGE PLANNING?}

There are a number of different ways in which language planning could be defined (see for example Cooper 1992; Laitin 1992). The most widely known and oft-quoted definition of language planning is, however, the one proposed by Jernudd and das Gupta 
(1971) who describe language planning thus: "The term language planning refers to an organised pursuit of solutions to language problems typically at national level". This should not be construed as implying that language planning does not occur at lower levels than the state and in other areas as well, for example corpus and acquisitional planning. The aspect about language planning which is most germane to my current argument is its futuristic nature. Language planning is futuristic because it involves having to make decisions between competing alternatives and provides the intellectual with unique opportunities to be both prophet and academician. The argument is expressed forcefully by Appel (1993: 231):

When intellectuals use academic knowledge to develop policy they present themselves as prophets, censuring society and mentoring it towards the future. Here is another difference between academic theory and policy; academic theory is principally aimed at explaining the past and the present; extrapolations into the future, as economics shows, are notoriously unreliable, while policy work looks into the future.

If one of the pre-conditions for the continued popularity of language planning in South Africa is an unstable political environment, my guess is that language planning is unlikely to continue being popular in South Africa for some time to come. To quote Du Plessis once more, "as a fad it is likely to blow over soon". However, the conditions which engender its popularity seem to have been reinforced rather than weakened with the passage of time.

In a stable world of complete equilibrium, where each day is very much like the one before it and the other one to come, and where all members of society are satisfied with their condition, language planning would be unlikely" (Cooper 1989: 165).

If planning is futuristic, it is not surprising that it is not only language which is being planned. Planning is taking place in a number of diverse areas including, but not restricted to, housing, education, health etc. It can be argued that language planning belongs to a cluster of activities which are all primarily concerned with strategies of manipulation, either part of redress or as a subtle way of sustaining existing inequalities.

In some circles because of an exaggerated belief in the power of policy to bring about educational change, a shift in language policy is hailed as "a panacea to a particular educational problem", but as Treffergarne (1986: 143) warns while discussing his French West African experience, the policy may be "scapegoated" if the educational policy goes sour or even worsens. Appel (1993: 233) cautions about South Africa in a rhetorical form: "Is it difficult to imagine that when policies fail to solve educational problems, terror and dogmatism will prevail?"

Language policies may be scapegoated or give rise to dogmatism not only because they have not been successfully implemented, but because of the way they have been conceptualised. One of the consequences of language planning belonging to a repertoire of other planning activities is the tendency to compare planning language with planning other areas of human experience, notably economics. Although the comparison is inevitable and may be illuminating, it overlooks the fact that language, unlike other resources such as economics, is symbolic, i.e. it is value loaded.

Restating the position in Jernudd (1971) that it is unnecessarily simplistic for language planners to believe that language is easily amenable to planning, Laitin (1991: 151) notes that. "language planners seem to be unaware of the fate of their brethren in urban and economic planning where lofty goals have long been subverted by grim reality". Cynically, I would add that language planning, although seemingly futuristic, is an attempt to redress current educational problems using anachronistic models drawn from disciplines such as economics. 
In the third and final part of this paper, I argue that discussions about the various policy options are futile unless they address issues of implementation. Policies in themselves do not bring about change, but the way they are implemented could bring about change. "Detailed implementation is the essence of change" (Ferguson 1993). It is therefore unfortunate that language specialists have so far been more preoccupied with policy options than addressing issues on implementation.

\section{WHAT IS IMPLEMENTATION?}

Because implementation is concerned with strategies of translating ideas into action, it is an exercise in continuous experimentation and not a delivery date. It is unnecessarily simplistic to regard implementation as consisting of putting predefined ideas into action. In some cases a more robust and flexible policy may be a by-product and not a precursor of exercises in implementation.

If the aim of any policy implementation is to achieve certain goals, it becomes necessary to build into the implementation exercise a mechanism for determining whether the policy has realised its intended goals.

In other words: a policy has to be evaluated.

There are two main problems for language education policy in restricting evaluation to the end of the implementation exercise.

First, given the uncertainty about the "gestation period" of language (Berretta 1992), it is difficult to know when the summative evaluation should begin. Secondly, when an evaluation is restricted to the end of a programme (assuming the end point can be identified), the evaluation loses its power to influence the policy currently in operation. The alternative is for the policy to be shadowed by its own evaluation. Concurrent evaluation has the merits of shadowing and consequently forming the development of the policy, hence potentially pre-empting problems which might arise during the implementation, but were not foreseen at the beginning of the programme: It is, however, naive to assume that all problems of implementation can be seen in advance (Ferguson 1993).

In the South African context a more radical proposal has to be made. The evaluation which has to take the form of some fact-finding "mission" may have to be carried out. The aim of the fact finding will be to assess the degree to which the situation is sensitive to innovation. Makoni (1993) elaborates on this type of evaluation.

Educationally, an evaluation preceding implementation provides information about what the situation was like before the language policy was implemented. For the applied linguist the type of evaluation provides opportunities for a gathering of baseline data which enables comparisons to be made with the situation developing after implementation.

"Interest in this aspect of language education is increasing and more systematic attempts at describing the status quo ante, rather than relying on or referring to anecdotal or assertive accounts of the situation, are being developed" (Anderson 1985: 287).

The aim of investigating the status quo ante is to try and test the degree of fit between the nature of the context and the ideas to be implemented. Investigations into the degree of fit between ideas and context can be followed by a pilot project. Unfortunately pilot projects, although desirable, do not guarantee successful dissemination. Because of the special circumstances of pilot projects, their implementation is "doomed to success" as Crossley (quoted in Ferguson 1993) puts it. The morale of the "tale" is that implementation is a complicated process and may have to be carried out on a piecemeal basis, and even this does not guarantee its success. 


\section{IMPLEMENTATION AT STATE LEVEL}

There are a number of institutions which can be involved in language policy implementation including governments. In my view Davies (1986: 6) argues correctly that governments rarely make or are able to make overall decisions. What often happens is that policies are partially implemented and indeed partially interpreted because in some cases governments may lack the necessary political, human and material resources to implement the policy. Implementation also requires contingency resources because resources required to carry out routine system-maintenance may have to be expanded or reorganised to cater for innovation. Any language educational policy has to compete for resources with other areas of human experience which are also engaged in their own planning. Whether a government is to allocate the necessary resources to language education depends on the priorities which are set by that government:

I strongly feel that in situations of diminishing resources and keen competition from more deserving areas such as health, housing, etc., language education is not likely to be regarded as a top priority, irrespective of what we as applied linguists might like to believe. If language education is not regarded as a top priority, resources allocated to it may not be sufficient for a full implementation of the policy, and implementation of language educational policies normally requires considerable resources. For example, if all the eleven officially recognised South African languages were to function as media of instruction, materials would have to be provided in each of the individual languages. Provision of these materials is very expensive and requires a high degree of expertise. Hard economic realities mean that governments rely heavily on commercial publishers. Unfortunately, because "economies of scale" dictate that publishers invest in instructional materials for languages with relatively large number of speakers, it means that languages with relatively few speakers such as Pedi, Venda, etc. may not receive fair treatment.

The issue of resources for implementing media of instruction requires that the issue of what constitutes a language for instructional purpose must be addressed. It is relatively easy to determine what constitutes a language for instructional purposes in speech communities in which communities are prepared to overlook dialectal diversity. Unfortunately, this is not always the case because "minor dialectal variations may be viewed locally as so significant that the exclusion of one variety from an educational role may constitute an affront to the particular group" (Ferguson 1988).

\section{CONCEPTUAL CLARITY}

Implementation of a policy requires some form of conceptual clarity on the part of those who are to implement the policy. Arguments about the desirability of each child receiving instruction in its mother tongue, which are questionable on cognitive grounds (see Makoni 1993), run into problems over what constitutes the mother tongue, first on linguistic grounds and secondly on sociolinguistic criteria.

Linguistically, the concept of mother tongue has been questioned on the basis of the way it avoids issues of dual first language shift, cases of language loss, language standardisation, etc. Can a child who speaks a non- standardised dialect at home, receiving instruction in a standardised dialect, be said to be benefiting from mother tongue instruction? Can you claim to be a mother tongue speaker of all the different dialects of your language? It is presumptuous for me to claim to be a mother tongue speaker of the various dialects of Shona if the variety of language which I speak may be classified as a dialect of Shona. How can I be a mother tongue speaker of dialects which I do not know? Furthermore, since we all attend school in a "non-home code", can anyone be said to have attended school in his or her mother tongue? An even more powerful argument would question the entire basis of the notion of a mother tongue by arguing that, since there is a considerable amount of individual variation between speakers of the same mother tongue because "all grammars leak", the only language one can be a mother tongue speaker of is one's idiolect (Davies 1986). 
Perhaps Paikeday (1985) is right in his dramatic claim that "the Native speaker is dead". To implement a policy in which students are said to learn through their mother tongue may be seen then as a serious attempt at implementing a fictitious and highly idealised construct.

In the South African context, sociolinguistically the implementation of mother tongue education, if I may call it that, is complicated less by the heterogeneity which is characteristic of urban centres such as Johannesburg, as is frequently claimed (see Nelissa and Van der Berg 1993), than by the presence of urban argots which may be the mother tongue of many urban-dwellers. These urban argots or "antilanguages", as Halliday (1992) would call them, are rarely counted. For example, in the recently announced eleven languages policy for South Africa the urban argots were not included when the number of African languages were given, perhaps because they are not standardised. Street (1992) puts it neatly when he writes, "A major problem with this strategy is the artificiality of the concept of mother tongue. Young children living in urban townships may find themselves living next door to Nguni speakers, across the road from Sesotho speakers, whilst their parents derive variously from Xhosa or other language groups. Their everyday "first language", then, may be some sort of urban Creole " ... such children when they enter school have a "mother tongue" designated for them and have to spend three or four years learning through it even though it is as alien as English" (Street 1992: 34). The degree of African multilingualism is clearly being constrained by the Creolisation of urban African linguistic mixtures suggesting that African urban centers may not be as multilingual as is frequently claimed.

Even if the resources were available and the conceptual issues surrounding mother tongue proficiency had been resolved, the implementability of the policy would finally depend on the language teacher's proficiency in the language designated and her expertise to initiate and sustain change - as Davies (1986: 2) puts it:

The key issues are how well trained the teachers are and in particular how good their proficiency is in the medium of instruction and what goes on at the local level within a school, within a classroom everyday.

The use of each of the official languages as media of instruction in initial education also has practical implications in the organisation and deployment of teachers. It means the calculation of teachers has to be conducted on a local linguistic level and not on a global level. This means that discrepancies in the availability of staff between various regions cannot in the short-term be addressed by drafting teachers from one region to another. For example, an undersupply of teachers from Venda cannot be redressed by recruiting from another region.

The impression I have so far created is that language policy can be implemented if certain conditions which I will restate are met:

(1) A government is willing and able to provide the necessary resources.

(2) Some clarity is reached on basic terms such as mother tongue.

(3) Teachers with the necessary commitment and expertise to explore the implications of the policy on a day-to-day basis are trained.

Closely related to the third condition would be the implementation of a policy as part of the so-called grassroots movement. A bottom-up process is an attractive way of initiating change, particularly in situations in which a government is perceived as illegitimate in the eyes of members of the community. Bottom-up strategies are preferred by Western agencies and leftwing academics (see Alexander 1992). Each strategy, however, has its own strength and weaknesses. The advantage of a top-down approach is that the state provides the necessary human and material resources which 
may be required to facilitate the implementation of the policy, hence increasing the chances of a long-term survival and institutionalisation of the change the policy seeks to bring about.

I am not as optimistic as Alexander (1992) and White (1992) that grassroots involvement necessarily makes decisions about implementation more democratic and that decentralisation necessarily improves the quality of decision making. The disadvantages of a bottom-up implementation strategy is that the policy is easily subverted in the name of rendering it more context-sensitive. Conversely, a top-down strategy is more difficult to subvert, but unfortunately the policy may not be rendered easily implementable because it is not adequately sensitive to the ideals and aspirations of the communities in which it has to take effect. In reality what is required is a mixture of top-down and bottom-down strategies with local initiatives exerting upward - pressures on national policies and national policies imposing downward pressure - so that local initiatives can reflect national policies.

But whether the strategies are going to be more top-down than bottom-up depends on the degree to which the institutions are coupled, with loosely coupled states likely to opt for more bottom-up than top-down implementation and more tightly coupled systems opting for more top-down and bottom-up strategies.

\section{$\begin{array}{lllll}\text { SUBVERSION AND RESISTANCE TO LANGUAGE POLICY } & \text { TO }\end{array}$ IMPLEMENTATION}

Resistance to a policy may not necessarily be a bad thing, just as supporting any innovation is not necessarily always a good thing. Most language policies invite opposition particularly if the policy is seen as detrimental to the interests of the group. Successful language policy implementation may need to take into account the views of the resisters. Attempts to take into account the views of resisters may lead to a reconceptualisation of a policy.

Klein (1967: 36) feels that resisters are best described as defenders. Implementation of language policy may be more successful if the positions of the defenders are taken into account. Resisters of a policy should be distinguished from saboteurs. Policy saboteurs are those who, on the one hand, are articulating arguments in support of a policy, but are undermining it by their activities; a situation which emerges as Laitin (1992) puts it when "public and private interests are in conflict, resulting in a private subversion of public good".

The classic example of saboteurs is that of Tanzanian bureaucrats, who on the one hand publicly supported Swahilisation, and on the other hand, set up private schools in which English remained the medium of instruction.

\section{CONCLUSION}

In this paper I have sought to provide some limited evidence concerning the popularity of language policy issues. I have argued that an attempt to explain the popularity of language policies may shed insight into the way language policy is conceptualised. The final part of the paper has sought to demonstrate that unless adequate attention is paid to issues of implementation, the preoccupation with policy issues in Applied Linguistics is unwarranted. 


\section{REFERENCES}

Alderson, JC. 1992. Guidelines for the evaluation of language education. In Beretta, A and JC Alderson (eds).

Alexander, N. 1992. Language policy from the grassroots. In K Herbert (ed.).

Appel, S. 1993. Chalk and cheese. Reflections of Educational Policy, Vol 14(2): 229 239.

Beretta, A and Alderson, JC (eds). 1992. Evaluating second language education. New York: Cambridge University Press.

Cooper, L. 1992. Language planning and social change. Cambridge: Cambridge University Press.

Davies, A. 1977. Introduction in testing and experimental methods. In The Edinburgh Course in Applied Linguistics, Vol 4.

Davies, A (ed.). 1986. Introduction to University of Edinburgh Working Papers: Language Education in Africa.

Davies, A (ed.). 1993. Speculation and empiricism in Applied Linguistics. University of Edinburgh Working Papers in Applied Linguistics, 4(14).

Du Plessis, LJ. 1987. Language planning: promoter of ideologies. In D. Young (ed.).

Ferguson, G. 1993. Implementing innovation in language education. University of Edinburgh Working Papers in Applied Linguistics, 4: 27 - 40.

Halliday, MAK. 1992. Language as social semiotic. London: Edward Arnold.

Herbert, K (ed.). 1992. Language in society in Africa. Johannesburg: University of the Witwatersrand Press.

Jernudd, B and das Gupta, J. 1977. Towards a theory of language planning. In J Rubin and $B$ Jernudd.

Kashoki, ME. 1982. Rural and urban multilingualism in Zambia: some trends. International Journal of the Sociology of Language, 34.

Kennedy, C (ed.). 1989. Language planning and English language teaching. New York: Prentice Hall.

Laitin, D, 1992. Language repertoires and state construction in Africa. Cambridge: Cambridge University Press.

Lyons, J. 1992. Language and linguistics. Cambridge: Cambridge University Press.

Makoni, SB. 1993. Mother tongue education: a literature review and proposed research design. South African Journal of African Languages.

Paikeday, TM. 1985. The native speaker is dead. Toronto and New York: Paikeday Publishers.

Phillipson, R and T Skutnabb-Kangas. 1994. English, panacea or pandemic? Sociolinguistic special issue of English Only. 
Rubin, J and B Jernudd (ed.). 1977. Can language be planned? Hawaii: University of Hawaii. Press.

Spencer, JC (ed.). 1971. Language in West Africa. London: Longman.

Tollefson, JW. 1989. The role of language planning in second language acquisition. In C Kennedy (ed.).

Treffgarne, C. 1986. Language policy in Francophone Africa: scapegoat or panacea? In A Davies (ed.).

Whitely, W. 1974. Language policies of independent African states. Reprinted in J Fishman. Advances in language planning. The Hague: Mouton.

Young, D (ed.) 1987. The planning and medium in education. Rondebosch: The Language and Education Unit and SAALA. 